\title{
MICROMORPHOLOGY AND ANATOMY OF LEAVES OF MORUS ALBA L. (MORACEAE) CULTIVARS FROM POLAND
}

\author{
MAegorZATA KLIMKO \\ Department of Botany, Poznań University of Life Sciences, Wojska Polskiego 71 C, 60-625 Poznań, Poland, \\ e-mail: klim@up.poznan.pl
}

(Received: December 3, 2015. Accepted: January 7, 2016)

\begin{abstract}
AвSTRACT. The article presents results of research on the micromorphology and anatomy of leaves of Morus alba cultivars. Mature leaves from generative shoots were collected in the Cytadela Park in Poznań and from trees planted along streets in different towns in the Wielkopolska region. A light microscope and a scanning electron microscope were used for observations. There were significant differences between the adaxial and abaxial epidermis. The idioblasts are found on the adaxial surface and stomata on the abaxial surface. Stomata can be classified into two types small and large. Several types of trichomes were recognized on the leaves: straight or hooked, unicellular, glandular capitate, spherical to elliptic stalked. Anatomical investigations revealed that leaves of $M$. alba cultivars were bifacial and the multi-layered mesophyll was diversified into palisade parenchyma and spongy palisade-like parenchyma. The research findings may be used for the identification of M. alba cultivars, while the epicuticular traits may be useful for the identification and classification of fragments of fossil leaves. The article includes descriptions and illustrations of several new quantitative and qualitative characters of the petiole and lamina, which have not been published previously and are described for the first time from Poland.
\end{abstract}

KeY WORDS: white mulberry, Morus alba, cultivars, Poland, petiole, lamina, anatomy, micromorphology, LM, SEM

\section{INTRODUCTION}

The genus Morus L. belongs to the family Moraceae, which originally belonged to the order Urticales, but recent advances in the molecular characterization of the family have placed it in the order Rosales (APG II 2003).

Morus is a genus of approximately 10-16 species distributed in Asia, Africa, North, Central and South America (Zhekum \& Gilbert 2003, Nepal 2008, Nepal \& Ferguson 2012, Seneta \& Dolatowski 2012, Nepal \& Wichern 2013). Mulberry (Morus sp.) is the only food plant for the silkworm (Bombyx mori Linn.) in China, which is an economically sericigenous important insect for the sericulture industry (Kumar 2011) and for fruits in Europe (Yashvanth et al. 2015). White mulberry is widespread in Southern Europe, in all temperate areas, also in the mountains of tropical Africa. In Europe white mulberry has been planted starting from the 11th-12th centuries and in many respects it is a highly variable species (SENETA \& Dolatowski 2012). Morus alba L. originally was endemic to Central and Northern China

The genus Morus comprises trees or shrubs with latex; monoecious or dioecious. Leaves alternate; leaf blade simple to deeply palmately lobed (juvenile leaves on long shoots), smooth and shiny, or slightly rough abaxially with tufts of white hairs; margin toothed; primary veins (3-5) from the base, secondary veins pinnate (ZheKum \& Gilbert 2003, Seneta \& DoLATOWSKI 2012). Morus identification is often based on highly variable morphological characters of the leaf and fruit colour. In Poland one species M. alba is commonly grown. According to some authors classified at the rank of cultivars: with blackish purple or purple syncarps var. alba and var. multicaulis with pale yellow to creamy white syncarps (ZHEKUM \& GiLBerT 2003). Morus alba var. multicaulis is also classified in the rank of species (Katsumata 1971, Kumar 2011). In Poland trees are frequently planted as ornamental plants, e.g. along roads and in parks (SzAFer et 
al. 1969). They are also suitable for tall hedges (oral communication by S. Korszun).

Leaves of different mulberry species have been investigated in micromorphological SEM studies, e.g. cv. 'Kanva 2 (K2)', Morus laevigata Wall., M. multicaulis Perrottet and M. serrata Rox. (KumAr 2011); M. alba (YASHVANTH et al. 2015); M. alba 'Minamisakari' (SuGIMURA et al. 1999); four mulberry cultivars: $\mathrm{V}_{1}, \mathrm{TR}_{10}$, $\mathrm{S}_{34}$, and Mysore local (Kumar et al. 2012) and in light microscope (LM) of M. alba, M. laevigata, M. multicaulis, M. nigra, and M. rubra L. (PhiLIP et al. 1989, АвBASI et al. 2014). In those studies examined material came from the tropical climate and focused on the abaxial surfaces of leaves.

The hypothesis of the present study is that leaves of $M$. alba cultivars are more variable than reported in previous literature. The main goal of this study was to describe and document the lamina and petiole micromorphology and anatomy.

\section{MATERIAL AND METHODS}

Mature leaves from generative shoots of two varieties Morus alba were collected in the Cytadela Park in Poznań and from trees planted along streets in different towns in the Wielkopolska region, e.g. Gorzów Wielkopolski, Jarocin, Kalisz, Poznań and Skwierzyna. Leaves of M. alba were collected from specimens with blackish purple or purple fruits = var. alba $(30$ trees) and with pale yellow to creamy fruits $=$ var. multicaulis (10 trees). Each specimen was represented by 20 leaves randomly collected from June to July 2015. The sculpture of both surfaces of leaves was studied on permanent slides with an Olympus BX 43 light microscope (LM) with camera lucida (KLIMKO et al. 2014)). Completely dried leaves were investigated with a SEM. Micrographs were taken with a SEM type EVO 40 (Carl Zeiss, Jena, Germany) at an accelerating voltage of $15 \mathrm{kV}$, at the Confocal and the Electron Microscopy Laboratory, Faculty of Biology, the Adam Mickiewicz University, Poznań, Poland. Prior to observations the prepared material was sputtered (for $15 \mathrm{~s}$ ) with gold by means of an SCB 050 ion sputter (Balzers AG Lichtenstein). Ten leaves of individual specimens were examined for the following traits: adaxial and abaxial surfaces of the epidermis, the sculpture of wax and cuticle. The study was documented with five microphotographs for each leaf. The photographs in LM were taken in magnification $\times 10$ and $\times 40$, and in SEM at various magnifications from $\times 200$ to $\times 10000$. For anatomical investigations living material was preserved in $70 \%$ alcohol. Transverse sections $50 \mu \mathrm{m}$ thick were prepared with a microtome (Leitz). Ten sections were taken from each petiole and lamina in the middle parts. All the sections were embedded in glycerine-gelatine and examined under a light microscope. Slides thus prepared were used to describe transverse sections (T.S.) and measured characters: size of epidermal cells, idioblasts, stomata, non-glandular trichomes, thickness of palisade and spongy mesophyll layers, thickness of epicuticular layer, ratio of the spongy mesophyll to palisade mesophyll thickness, number of vascular bundles. The thickness of the petiole and lamina was measured between the adaxial and abaxial surface and in the lamina without veins. The epidermal thickness index (ETI) was calculated as the ratio of the adaxial epidermis thickness to the abaxial epidermis thickness. The terminology of epicuticular waxes was applied according to BARTHLOTT et al. (1998) and that for types of trichomes by Kumar (2011).

\section{RESULTS AND DISCUSSION}

\section{LAMINA SURFACE}

Adaxial epidermis. The epidermal cells above veins were narrow and rectangular or elongated with acute ends. The anticlinal walls were straight (Figs 1-4). In SEM the anticlinal walls forming a boundary between the epidermal cells were depressed below the outer tangential surfaces of the cells (Figs 6, 9 ). There were no stomata on the adaxial epidermis. The periclinal walls were convex (Figs 5, 9). The epidermal cells in the intercostal areas were irregularly polygonal (Figs $6,8,9$ ) and the adaxial epidermal cells were larger than those on the abaxial side (Figs 6, 9, 20, 23). On the adaxial epidermis idioblasts, which were clearly distinguishable from the epidermal cells and trichomes, were very commonly found (Figs 1-5, 7). The shape was rounded or oval and it was identical in trees coming from different locations (Katsumata 1971, this study). The size of idioblasts in the cultivar with colored syncarps was variable, ranging from 17.3 to $43.7 \mu \mathrm{m}$ in length and from 13.1 to $42.4 \mu \mathrm{m}$ in width in the intercostal areas and from 18.6 to $38.6(-56.9) \mu \mathrm{m}$ in length and from 14.5 to $41.2 \mu \mathrm{m}$ in width in the costal areas. The size of idioblasts in cultivars with white syncarps was variable, ranging from 15.9 to $30.2 \mu \mathrm{m}$ in length and from 15.4 to $20.5 \mu \mathrm{m}$ in width on the intercostal areas, and from 21.8 to $43.6 \mu \mathrm{m}$ in length and from 21.7 to $38.8 \mu \mathrm{m}$ in width on costal areas. The idioblasts found on costal areas were sometimes larger and less numerous than those in the intercostal areas, which is consistent with previous studies by Katsumata (1971). Idioblast size in M. alba 'Minamisakari' grown on an experimental farm in Kyoto (Japan) ranged from 12 to $35 \mu \mathrm{m}$ (Sugimura et al. 1999). A high density of idioblasts was observed near the margin (Figs 1-4), and as it was reported by SugimuRA et al. (1999) - in the top leaf. The idioblasts may be found singly (Figs 2, 4, 5, 7) or with two adjacent idioblasts (Fig. 1). Sugimura et al. (1999) described the idioblasts on the adaxial surface of M. alba as dome-like protrusions. 
Measurements showed that the size of idioblasts varied between leaves from specimens with differently colored syncarps. In $M$. alba var. alba lithocysts were larger than those in var. multicaulis in the inter costal areas. Scarce unicellular straight or hooked trichomes were not mineralized and were situated on the main vein (Figs 11, 12). ABBAsI et al. (2014) reported that in $M$. alba with yellow to creamy syncarps on the adaxial surface peltate glands, non-glandular, unicellular trichomes and hooked hairs were present. The size of trichomes was 165 (20 to 250$) \mu \mathrm{m}$. There were epicuticular wax smooth in specimens from var. multicaulis (Figs 5, 6), and plates in specimens var. alba (Figs 9, 10). Cuticular striations were present in the epidermal cells (Figs 6, 8). PHILIP et al. (1989) reported that such a cuticle was observed on the abaxial surface. Wax and cuticle ornamentation were new features for M. alba.

Abaxial epidermis. Costal and intercostal areas conspicuous. The epidermal cells above the veins were elongated with acute or rectangular ends (Figs 13, 15). The epidermal cells in the intercostal areas were roundish, oval or polygonal (Figs 14, 16). The anticlinal walls were straight to slightly undulate (Figs $14,16)$. In SEM the cell boundaries were similar to those in the adaxial surface. The periclinal cell walls were convex (Figs 18, 20-23). The stomata were anomocytic (the ranunculaceous type), randomly oriented, oval in shape and were either on the same level of the epidermis or may be slightly elevated (Figs 20, $21,23)$. Based on the size of stomata they can be classified into two types: small and large (Figs 21, 23). PHilip et al. (1989) called these stomata normal and 'giant'. In specimens with pinkish white, purple or dark purple to black syncarps the size of small stomata was $14.3 \times 8.8 \mu \mathrm{m}$, and in large stomata this size was $21.1 \times 12.1 \mu \mathrm{m}$. In M. alba (with white syncarps) the size of small stomata was $13.6 \times 8.2 \mu \mathrm{m}$, and in large stomata the size was $19.3 \times 12.7 \mu \mathrm{m}$. In var. alba stomata were slightly longer. Small stomata were usually surrounded by 4 or 5 neighbouring cells, the large stomata were surrounded by $6(7-8)$ cells (Figs 14, 16). AbBasi et al. (2014) reported that the stomatal complex in $M$. alba from different areas of Lesser Himalayas was 17.5 (12.5 to 22.5$) \times 9.58$ (6.25 to 12.5$) \mu \mathrm{m}$, anomocytic or desmocytic, and they did not distinguish types of stoma sizes. Variation of stomata in terms of their size both in M. alba and in M. laevigata was shown by PHILIP et al. (1989).
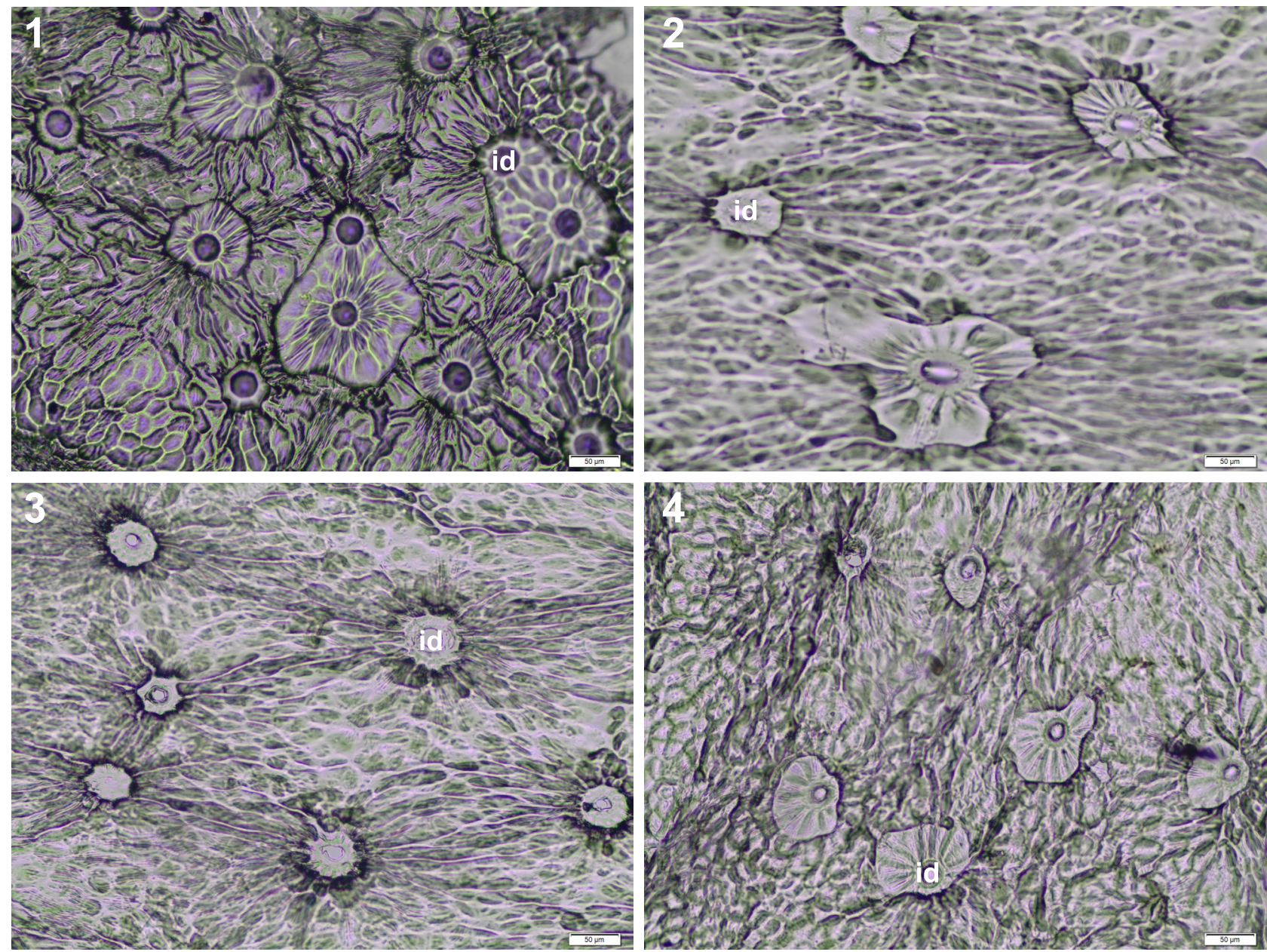

Figs 1-4. LM. Surface view of the adaxial epidermis of Morus alba: (1) var. multicaulis, (2-4) var. alba: id - idioblast 

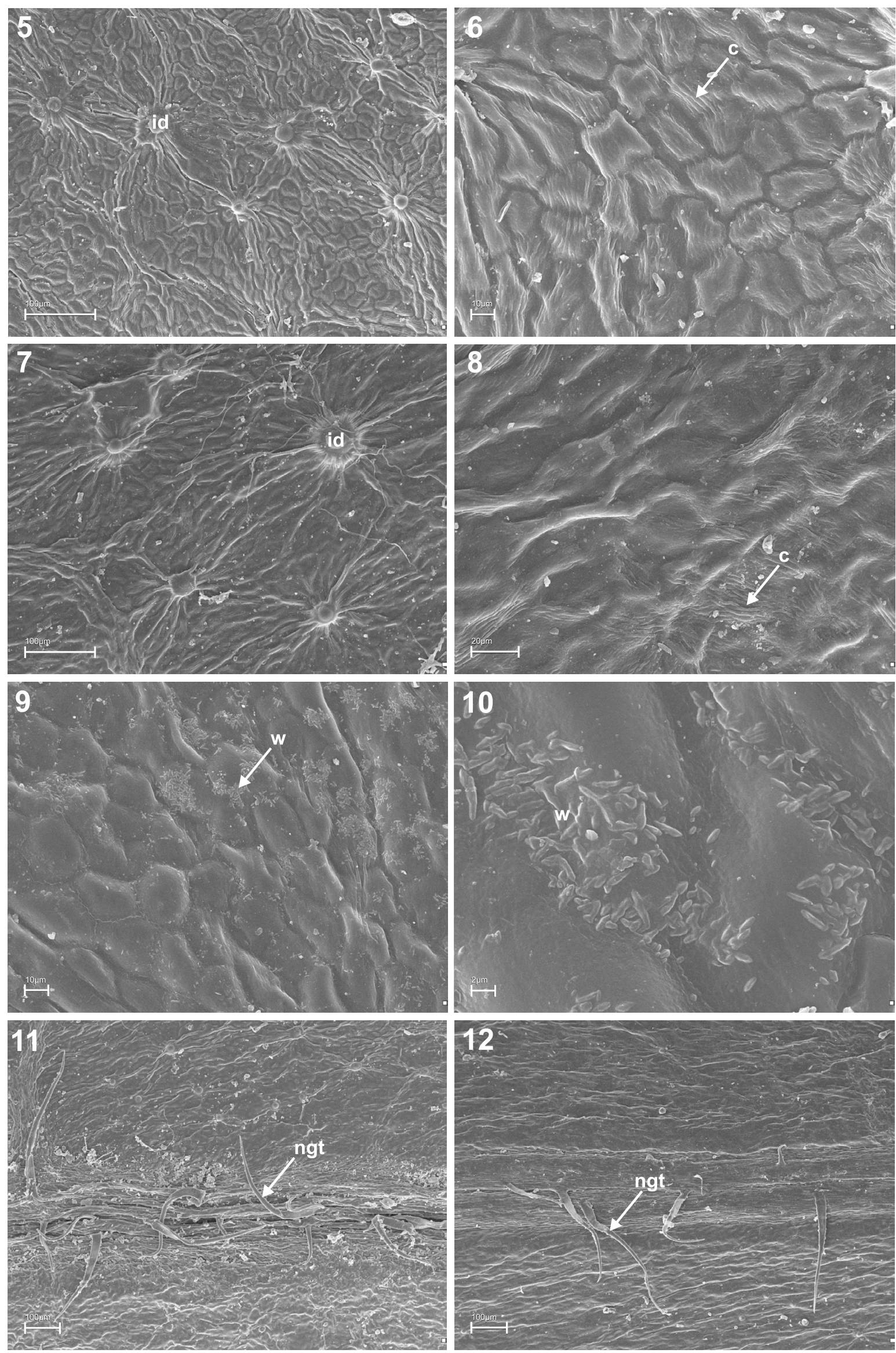

Figs 5-12. SEM. Surface view of the adaxial epidermis of Morus alba: $(5-6,11)$ var. multicaulis, $(7-10,12)$ var. alba: $c$ - cuticle, id - idioblast, $n g t$ - nonglandular trichome, $w$ - wax 

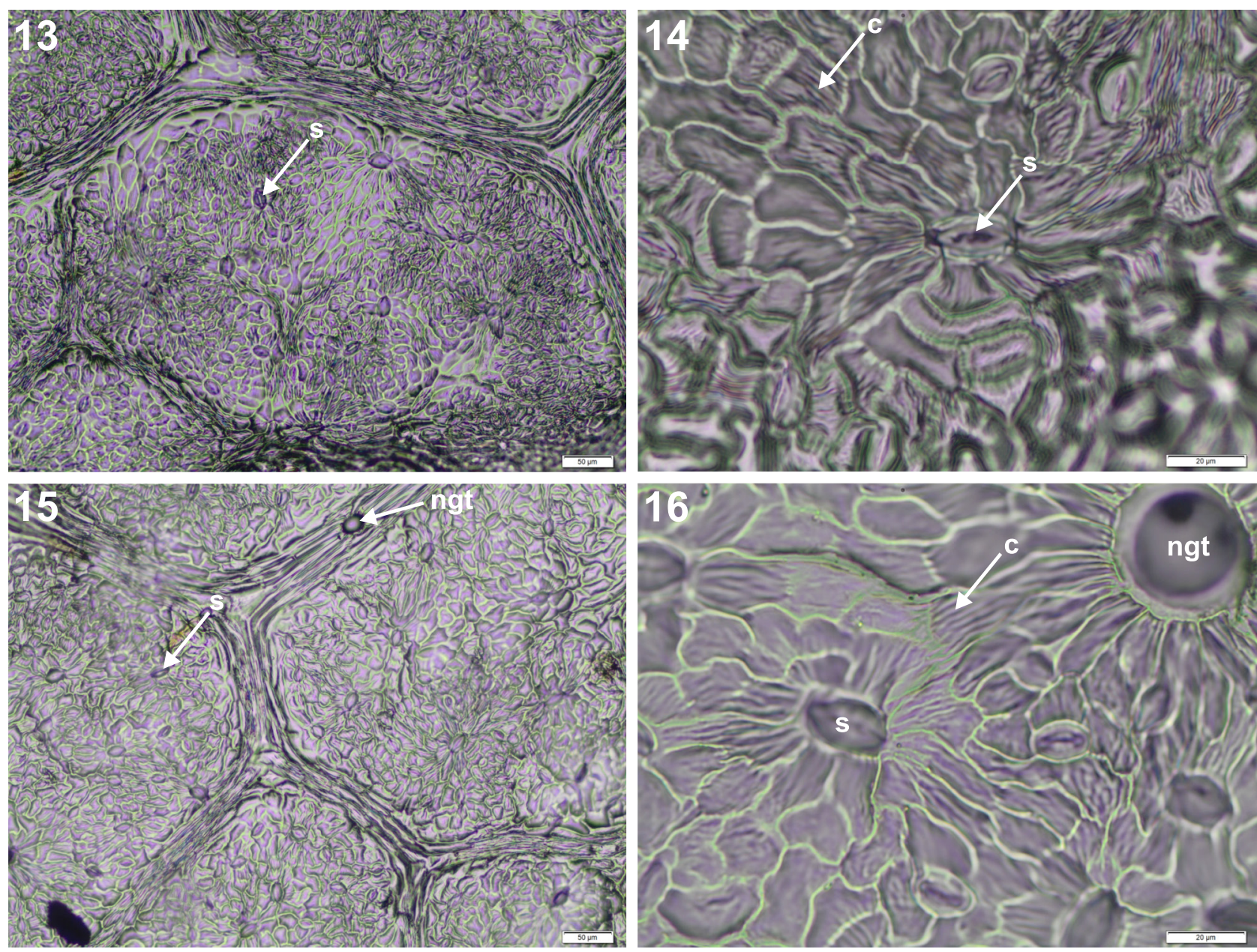

Figs 13-16. LM. Surface view of the abaxial epidermis of Morus alba: $(13,14)$ var. multicaulis, $(15,16)$ var. alba: $c$ - cuticle, ngt - nonglandular trichome, $s$ - stoma

Nonglandular trichomes were found on the abaxial epidermis in the costal and intercostal areas (Figs $15-19,22)$. The shape of nonglandular trichomes is oval, rounded with or without acute, short tips (Figs $18,19)$. The size of nonglandular trichomes in specimens of var. alba was variable and ranges from 21.6 to $36.5 \mu \mathrm{m}$ in length and from 18.8 to $34.5 \mu \mathrm{m}$ in width in the intercostal areas and from 14.2 to 29.8 $\mu \mathrm{m}$ in length and from 10.3 to $25.2 \mu \mathrm{m}$ in width in the costal areas. In M. alba var. multicaulis their size varied from 18.6 to $39.91 \mu \mathrm{m}$ in length and from 15.8 to $36.8 \mu \mathrm{m}$ in width in the intercostal areas and from 25.6 to $40.7 \mu \mathrm{m}$ in length and from 20.9 to $29.6 \mu \mathrm{m}$ in width in the costal areas.

Unicellular straight and hooked non-mineralized trichomes of various lengths were distributed along and few on the surface on leaf veins in var. alba (Fig. 25 ) and along the main vein in var. multicaulis (Fig. $24)$. The cuticle ornamentation on the abaxial surface was irregularly striated (Figs 14, 16, 20, 21 and 23 ), and is the same as on the adaxial epidermis. Wax ornamentation was not observed.

\section{PETIOLE SURFACE}

In $M$. alba both surfaces of petioles were more or less pubescent (Figs 26, 28-30). Unicellular non-mineralized, long trichomes with straight or hooked tips were observed (Fig. 26). The cuticle ornamentation was not observed, wax was peltate (Fig. 27), identical as on the adaxial surface of leaves in mulberry specimens with colored syncarps (Fig. 10).

\section{PETIOLE TRANSVERSE SECTION (T.S.; FIG. 31)}

Outline. The outline of petiole is slightly channeled on the adaxial surface and rounded on the abaxial surface. The average petiole thickness in the median part ranged from 994.9 to $1505.9 \mu \mathrm{m}$.

Cuticle. The epidermal cells were covered with an epicuticular layer. The average thickness of this layer was $1.62 \mu \mathrm{m}$ on the adaxial surface and $1.02 \mu \mathrm{m}$ on the abaxial surface.

Epidermis. The one-layered epidermis was made up of rectangular cells. The anticlinal cell walls were straight and the outer periclinal cell walls were flat on the adaxial surface and straight on the abaxial sur- 

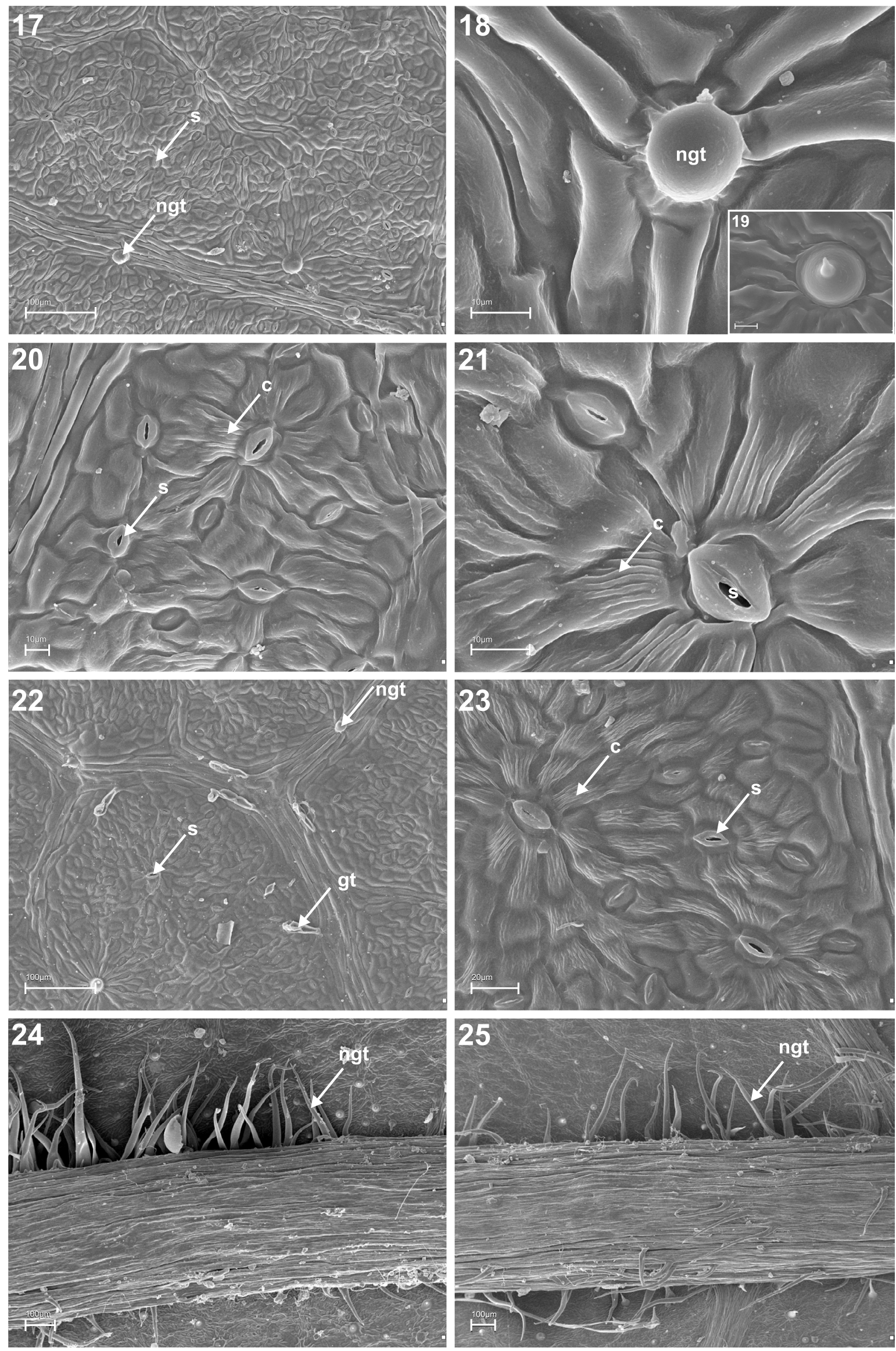

Figs 17-25. SEM. Surface view of the abaxial epidermis of Morus alba: $(17,18,20,21,24)$ var. multicaulis, $(19,22,23,25)$ var. alba: $c$ - cuticle, $g t$ - glandular trichome, $n g t$ - nonglandular trichome, $s$ - stoma 

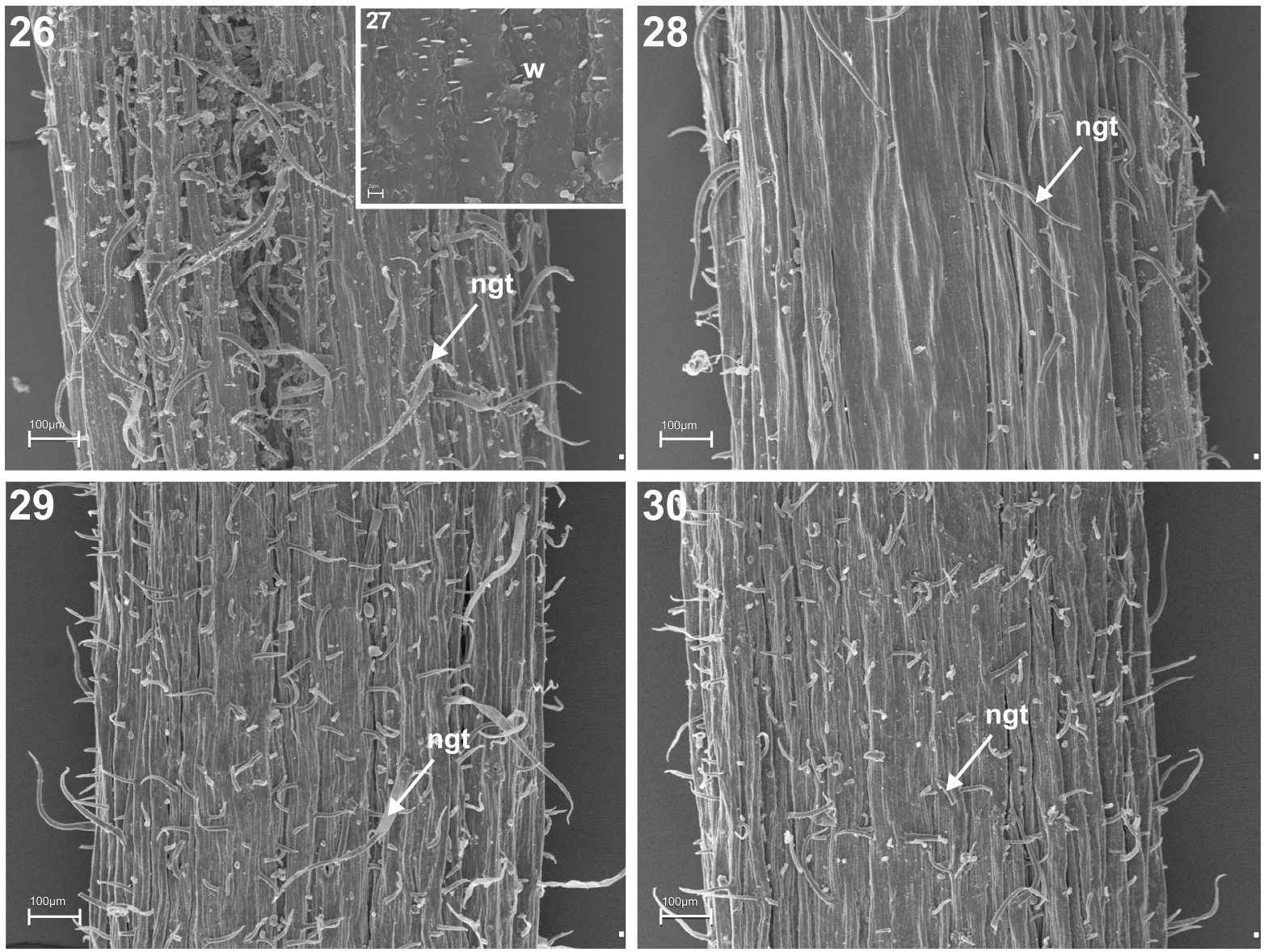

Figs 26-30. SEM. Surface view of the adaxial (on the left) and abaxial (on the right) epidermis of petiole of Morus alba:

(26-28), var. multicaulis, (29-30) var. alba: ngt - nonglandular trichome, $w$ - wax

face. The height of epidermal cells ranged from 11.6 to $16.3 \mu \mathrm{m}$ and from 7.1 to $12.4 \mu \mathrm{m}$ in width on the adaxial surface and from 8.8 to $12.3 \mu \mathrm{m}$ in height and from 7.1 to $10.1 \mu \mathrm{m}$ in width on the abaxial surface. The adaxial epidermis was thicker than the abaxial epidermis $($ ETI $=1.16)$. A few unicellular trichomes from 36.7 to $331.2 \mu \mathrm{m}$ long and simple glandular trichomes could be found. Stomata were rarely found on the adaxial and lateral surface of petioles.

Outer tissues. The 2-3 layers of chlorenchyma was found beneath epidermis. Moreover 5-6 layers of the angular collenchyma was located on the adaxial side and (5-) 7-8 layers on the abaxial side and laterally. The parenchyma cells thin walls were multilayered without intercellular spaces.

Vascular bundles. In the case of petiole anatomy the shape of vascular bundles was similar. The centre of the petiole was occupied by 4, 5, 8 (var. multicaulis) and 5-7 (var. alba)) collaterally vascular bundles. In the case of petiole anatomy studied in 31 varieties by NADERUZZAMAN et al. (1994) the shape of vascular bundles was similar, but the numbers ranged from 5 to 11 . The parenchymatic tissue separated the vascular bundles from one another. The lignified xylem faced towards the adaxial petiole surface, while the phloem faced towards the abaxial epidermis. The

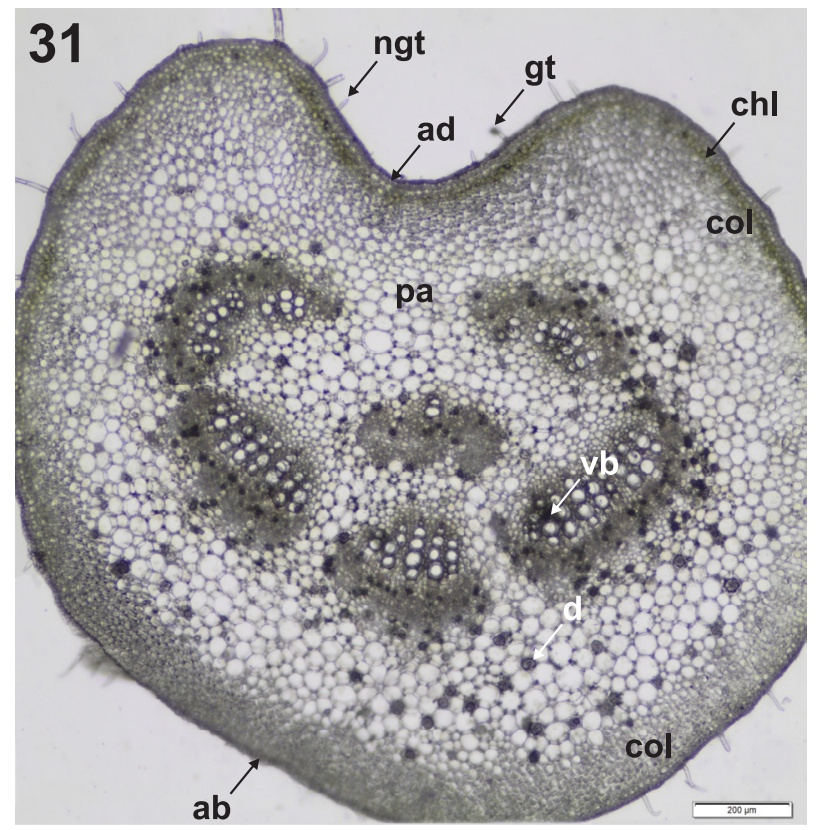

Fig. 31. LM. Petiole transverse section (T.S.) of Morus alba. T.S. of the petiole illustrating the forms and general anatomy: $a b$ - abaxial surface, $a d$ - adaxial surface, chl - chlorenchyma, col - collenchyma, $d$ - druse, gt - glandular trichome, ngt - nonglandular trichome, $p a-$ parenchyma, $v b$ - vascular bundle 
cells contained calcium oxalate druses, irregularly dispersed of average size $18.7 \times 15.7 \mu \mathrm{m}$ in the parenchyma cells and in vascular bundles.

\section{LAMINA TRANSVERSE SECTION (T.S.)}

Cuticle. In leaves the cuticle on the abaxial epidermis was thicker than the cuticle on the adaxial surface (Fig. 33). The average thickness of the epicuticular layer ranged from 1.3 to $1.6 \mu \mathrm{m}$ (var. multicaulis) and from 1.0 to $1.7 \mu \mathrm{m}$ (var. alba) on the adaxial surface and from 1.3 to $1.5 \mu \mathrm{m}$ on the abaxial surface in both varieties.

Epidermis. The leaf epidermis consisted of single layers (Figs 32-34). The anticlinal walls were straight and slightly repand, whereas the outer periclinal walls on the adaxial surface were plane or slightly convex on the abaxial surface (Figs 33, 34). There were significant differences in the epidermal thickness. The average epidermal thickness ranged from 19.5 to $36.5 \mu \mathrm{m}$ (var. alba) and from 14.6 to 25.7 $\mu \mathrm{m}$ (var. multicaulis) on the adaxial surface and from 5.1 to $12.3 \mu \mathrm{m}$ (var. multicaulis) and from 5.9 to 12.9 $\mu \mathrm{m}$ (var. alba) on the abaxial surface. The reciprocal proportion of the height to width in the epidermal cells in var. alba was 1.45 and in var. multicaulis 0.96 on the adaxial surface and 0.65 (var. alba), 0.55 (var. multicaulis) on the abaxial epidermis. The adaxial epidermis was thicker than the abaxial epidermis ETI = 2.3 (var. multicaulis) and 2.8 (var. alba). In white mulberry cystoliths develop containing idioblasts in the adaxial epidermis (Figs 32-34). In leaves of Morus spp. there are three types of idioblasts, i.e. idioblasts with a small projection, with a medium projection and with a big projection (Katsumata 1971). Present studies showed that in M. alba cultivars the lithocysts in T.S. had no projection (Figs 32-33). KaTsUMATA (1971) reported in M. alba from Japan the idioblasts with a small or a medium projection and in those from Vietnam only with a small projection. NADERUZZAMAN et al. (1994) stated that in the 31 white mulberry cultivars examined in their study they found idioblasts without projections in five cultivars and in the other varieties they were with projections. Cystolith morphologically differs among mulberry cultivars and this might be useful as a criterion for classification (SugimuRA et al. 1999).

Mesophyll. The mesophyll was bifacial with a thicker spongy layer below the palisade. The palisade parenchyma was present in $1(-2)$ layers (Figs 33,34 ). The spongy parenchyma was present in four layers of elongated, short cells without air spaces (Figs 33, 34) and was located close to the abaxial face. The inner and abaxial mesophyll layers were a palisade-like spongy parenchyma (Fig 34). Recorded results confirm earlier studies conducted by TRUCHAN (2015). The reciprocal proportion of the thickness spongy parenchyma to the thickness palisade parenchyma was 1.43 (var. multicaulis) and 1.36 (var. alba). In the family Moraceae the appearance of the spongy parenchyma is of taxonomical importance. Three variations can be distinguished, namely typical spongy parenchyma, palisade-like parenchyma and aerenchymatous spongy parenchyma (VAN GREUNING et al. 1984). Kumar et al. (2012) studied leaves of four cultivars of mulberry and stated that the mesophyll was 8-10 layers with large air spaces.

Vascular bundles. In T.S. of the lamina vascular bundles were collateral as in petioles. The xylem faced the adaxial lamina surface, while the phloem faced the abaxial epidermis. The vascular bundles were surrounded by a sclerenchyma sheath. The bundle sheath extended to the adaxial and abaxial epidermis.

The midrib. The basic structure of the midrib was very similar in the cross-section between trees (Figs $35,36)$. The midrib thickness in the median part ranged from 671 to $963 \mu \mathrm{m}$ (colored syncarp) and from 719 to $725.7 \mu \mathrm{m}$ (white syncarp). The epidermis consistent of single layers. The anticlinal walls were straight. The epidermal cells on the adaxial surface were 1.3 higher than wider and 1.2 higher than wider on the abaxial surface. The adaxial epidermis was thicker than the abaxial epidermis ETI $=1.79$. Several unicellular trichomes (Fig. 35) and simple glandular trichomes could be found (Figs $37,38)$. Chlorenchyma in the leaf midrib was absent (Fig. 35). Below the epidermis over the entire circumference angular collenchyma composed of 5-6 layers was found on the adaxial surface and 4-5 layers on the lateral and adaxial surfaces (Fig. 35). The vascular system was recognized as an abaxial arc, clearly distinguished (Figs 35, 36). The xylem faced towards the adaxial midrib surface, while the phloem faced the abaxial epidermis. The parenchyma cells had thin walls, multilayered without intercellular spaces (Figs 35, 36).

Calcium oxalate and carbonate crystals. The calcium oxalate crystals in $M$. alba were mainly found as druses (Figs 35, 36) and prismatic crystals (Fig. 39). Druses were located in the cells of palisade and palisade - like spongy mesophyll layers of the lamina, in the leaf midrib and in the petiole (Figs 31, 35, 36). The prismatic crystals were found in the midrib (Fig. 39). Calcium carbonate crystals were observed in the lamina cystoliths and were located in the adaxial epidermis (Figs 32-33). Based on types of crystals, species of family Moraceae can be classified into three groups: (a) species with only calcium oxalate, e.g. Artocarpus altilis (Park.) Forberg; (b) species with only calcium carbonate: Fatoua pilosa Gaud. and Humulus scandens (Lour.), (c) species with calcium oxalate and carbonate, e.g. Broussonetia papyrifera (L.) L'Herit, Ficus elastica Rox., Morus australis Poir. (Wu \& KuoHuANG 1997). 

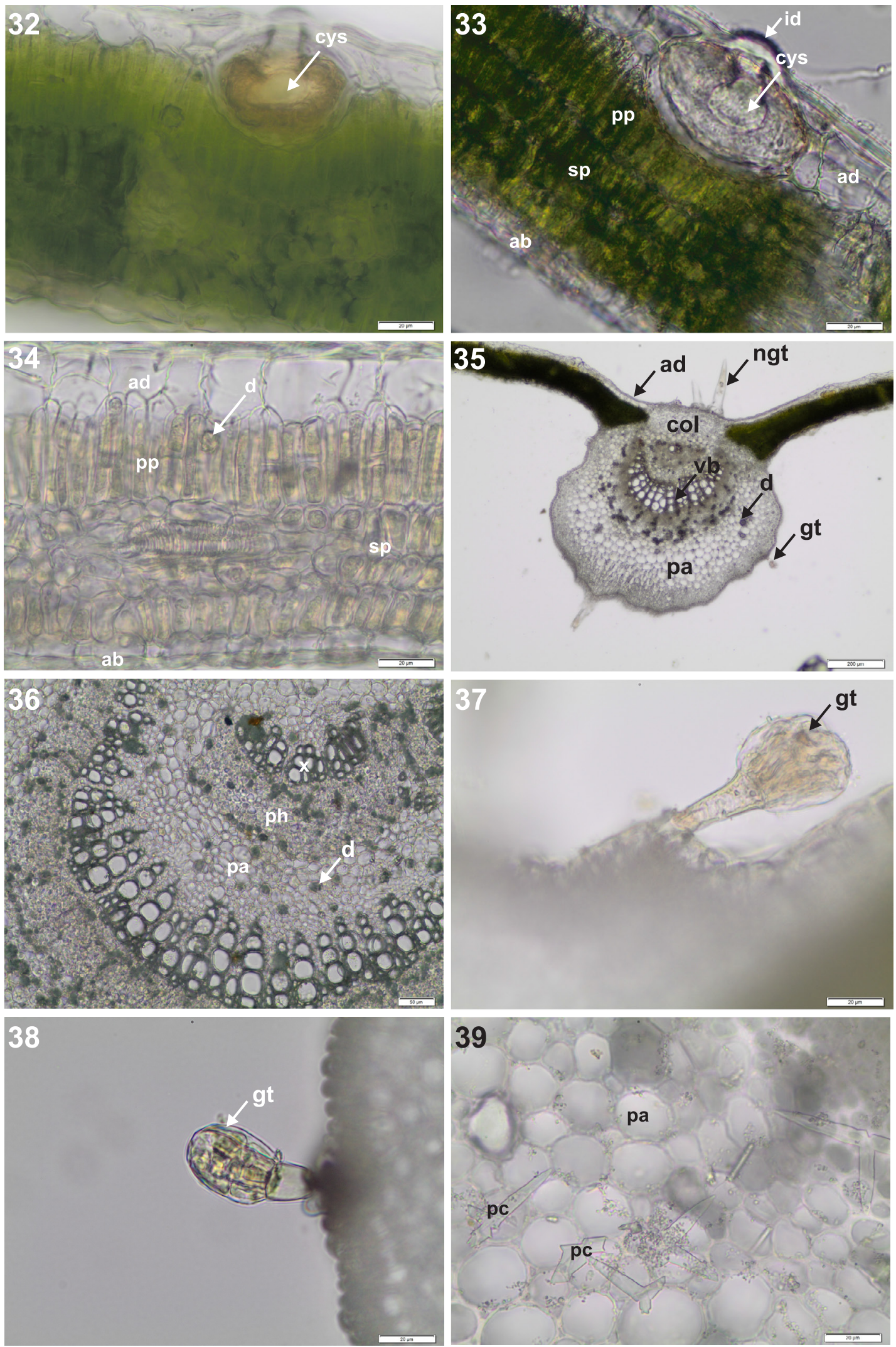

Figs 32-39. LM. Transverse section (T.S.) of lamina (32-34) and midrib (35-39) of Morus alba: (32-33) the idioblast connected to cystolith in a cystolith cavity, (34) T.S. of the lamina illustrating the forms and general anatomy, (35) T.S. of the midrib, (36) part of the vascular bundles in the midrib at high magnification, $(37,38)$ glandular trichome on the lateral side of the midrib, (39) prismatic crystals in the parenchyma cells of the midrib; $a b$-abaxial surface, ad -adaxial surface, col-collenchyma, cys - cystolith, $d$-druse, $g t$ - glandular trichome, $i d$ - idioblast, ngt - nonglandular trichome, $p a$-parenchyma cells, $p c$ - prismatic crystals, $p h$ - phloem, $p p$ - palisade parenchyma, $s p$ - spongy parenchyma, $x$ - xylem, $v b$ - vascular bundle 


\section{CONCLUSION}

The micromorphology and anatomy of leaves in Morus alba cultivars provided some important new data, e.g. wax peltate and cuticle characters, petiole and lamina pubescence, size of idioblasts, stomata and non-glandular trichomes. In $M$. alba leaves are hypostomatic and based on the size of stomata they can be classified into two types. Anatomical investigations revealed that leaves of $M$. alba cultivars were bifacial and the multi-layered mesophyll was diversified into palisade parenchyma and spongy palisade-like parenchyma. In Morus spp. the measurements of the epidermal features can be useful in specimen identification. Adaxial epidermal cells are larger than abaxial cells. The abaxial leaf side in M. alba provided more features of diagnostic value than the adaxial one. Many micromorphological and anatomical traits were present in leaves of different species of Morus (KumAR et al. 2012) and in leaves of different species of the genus Ficus L. (КьImKo \& TRUCHAN 2006) and they may be typical of the family Moraceae. When comparing traits of the anatomical leaf structure between trees with blackish purple or purple syncarps and with pale yellow to creamy syncarps it was found to be identical and the observed differences concerned primarily quantitative traits. Thus, this detailed analysis considerably broadened our knowledge of Morus cultivars.

\section{ACKNOWLEDGEMENTS}

I would like to thank Ilona Wysakowska for her technical assistance and Wojciech Klimko for his assistance with computer data records. The study was supported by the Department of Botany, the Poznań University of Life Sciences.

\section{REFERENCES}

Abbasi A.M., Khan M.A., Ahmad M., Munir M., Zafar M., Sultana S., Mishwani Z.R., Ullah Z. (2014): Ethnobotanical and taxonomic screening of genus Morus for wild edible fruits used by the inhabitants of Lesser Himalayas-Pakistan. Journal of Medicinal Plant Research 8(25): 889-898.

APG II (2003): An update of the Angiosperm Phylogeny Group classification for the orders and families of flowering plants: APG II. Botanical Journal of the Linnean Society 141: 399-436.

Barthlott W., Neinhuis Ch., Cutler D., Ditsch F., Meusel I., Theisen I., Wilhelmi H. (1998): Classification and terminology of plant epicuticular waxes. Botanical Journal of the Linnean Society 126(3): 237-260.

Katsumata F. (1971): Shape of idioblasts in mulberry leaves with special reference to the classification of mulberry trees. Journal of Sericultural Science of Japan 40: 313-322.

Klimko M., Truchan M. (2006): Morphological variability of the leaf epidermis in selected taxa of the genus Ficus (Moraceae) and its taxonomic implications. Acta Societatis Botanicorum Poloniae 75(4): 309-324.

Klimko M., WaWRZyŃSKa M., Wiland-SzymańsKa J. (2014): Comparative leaf morphology and anatomy of some neotropical Philodendron Schot (Araceae) species. Steciana 18(3): 159-171.

Kumar V. (2011): Ultrastructural study on the leaf surface of four mulberry (Morus sp.) genotypes and the influence of foliar trichomes on egg layings by Spilosoma obliqua (Wlk.) (Lepidoptera Arctiidae). Redia 94: 3-11.

Kumar V., Kodandaramaiah J., Rajan M.V. (2012): Leaf and anatomical traits in relation to physiological characteristics in mulberry (Morus sp.) cultivars. Turkish Journal Botanical 36: 683-689.

NaderuZzaman A.T.M., Roy A.K., Zahan S.K., Ahad A. (1994): Role of some leaf characters in the taxonomy of Morus alba L. in BSRTI (Bangladesh Sericultural Research and Training Institute Rajshahi). AGRIS 5: 47-50.

NePal M.P. (2008): Systematics and reproductive biology of the genus Morus (Moraceae). Ph.D. Dissertation. Kansas State University, Manhattan, KS.

Nepal M.P., Ferguson C.J. (2012): Phylogenetics of Morus (Moraceae) inferred from ITS and trnL-trnF sequence data. Systematic Botany 37: 442-450.

Nepal M.P., Wichern D.J. (2013): Taxonomic status of red mulberry (Morus rubra) Moraceae at its Northwestern boundary. Proceedings of the South Dakota Academy of Science 92: 19-29.

Philip T., Govindaiah T.P., Sengupta K., SuryanarayaNA N. (1989): Ontogeny of foliar stomata and trichomes in mulberry (Morus L.). Current Science 58(9): 506-508.

Seneta W., Dolatowski J. (2012): Dendrologia. Wydawnictwo Naukowe PWN, Warszawa.

Sugimura Y., Mori T., Nitta I., Kotani E., Furusawa T., Tatsumi M., Kusakari S.I., Wada M., Morita Y. (1999): Calcium deposition in idioblasts of mulberry leaves. Annals of Botany 83: 543-550.

SZAFer W., KulCzyŃski S., PAWŁowski B. (1969): Morus L. In: Rośliny polskie. PWN, Warszawa.

Truchan M. (2015): Morphological and anatomical variations of leaves in selected taxa from family Moraceae and their taxonomical importance. Wydawnictwo Naukowe Akademii Pomorskiej w Słupsku, Słupsk.

Van Greuning J.V., Robbertse P.J., GrobbelaAr N. (1984): The taxonomic value of leaf anatomy in genus Ficus. South African Journal of Botany 3: 297-305. 
Wu Ch., Kuo-Huang L.L. (1997): Calcium crystals in the leaves of some species of Moraceae. Botanical Bulletin of Academia Sinica 38: 97-104.

Yashvanth S., Rani S.S., MadhavendRa S.S. (2015): Morus alba L. New perspective: scanning electron microscopic, micro chemical, GC-MS and UPLC-MS characterisation. International Journal of Research in Pharmacy and Chemistry 5(1): 106115.
ZheKum Z., Gilbert M.G. (2003): Moraceae. In: Z.Y. $\mathrm{Wu}$, P.H. Raven, D.Y. Hong (eds). Flora of China 5: 21-73.

For citation: KLIMKo M. (2016): Micromorphology and anatomy of leaves of Morus alba L. (Moraceae) cultivars from Poland. Steciana 20(2): 73-83. doi: 10.12657/steciana.020.009 